\title{
The Community of Ardeidae Family and Distribution of Nest Trees in Pulau Rambut Wildlife Sanctuary, Jakarta Bay, Indonesia
}

\author{
Maya Safira Firdausy ${ }^{1, *}$ Ani Mardiastuti ${ }^{2}$, Yeni Aryati Mulyani ${ }^{3}$ \\ ${ }^{1}$ Forest Resources and Ecotourism Conservation Student Association, Department of Forest Resources and \\ Ecotourism Conservation, Faculty of Forestry, IPB University \\ ${ }^{2}$ Department of Forest Resources Conservation and Ecotourism, Faculty of Forestry, IPB University \\ ${ }^{3}$ Department of Forest Resources Conservation and Ecotourism, Faculty of Forestry, IPB University \\ *Corresponding author. Email: fmayasafira@gmail.com
}

\begin{abstract}
Pulau Rambut is a small island in Jakarta Bay that has been used as a breeding and roosting habitat for various waterbird species, especially the Ardeidae family. The study aimed at estimating Ardeidae family abundance and mapping the distribution of nest trees. The study was conducted in January-February 2020. Birds were counted using the census method, while the coordinates of nest trees were taken to map their distribution. There were eight Ardeidae family species (grey heron, purple heron, little egret, intermediate egret, cattle egret, great egret, pacific reef heron, and black-crowned heron). Ardeidae family's abundance was 3,681 individuals dominated by egret species (47\%) and black-crowned night heron (39\%). The number of waterbirds decreased sharply compared to previous studies. Nest trees were distributed mostly in the east of the island, consisted of 3 sub-colony.
\end{abstract}

Keywords: Abundance, Ardeidae, Census, Distribution, Pulau Rambut, Waterbirds

\section{INTRODUCTION}

Pulau Rambut is a small island in Jakarta that has been used as a breeding and roosting habitat for various waterbird species [1]. Most of the waterbirds on Pulau Rambut foraged in the morning to Java island or other islands around Kepulauan Seribu and returned in the evening to rest [2]. The abundance and distribution of waterbirds in Pulau Rambut were reported based on previous studies in 1990 and 2001 [3, 4]. This study found 15 species of waterbirds that were grouped into settled and non-resident waterbirds, especially the Ardeidae family. Based on previous studies, no recent research has been conducted on Pulau Rambut. Given the changing conditions of Pulau Rambut, it is necessary to research the abundance and distribution of nest trees to obtain the latest data on the Ardeidae family's abundance.

The study aimed to estimate waterbirds abundance, compare waterbirds species and abundance data with previous studies in 1990 and 2001, and map the distribution of nest trees. The research was conducted in January-February 2020.

\section{METHOD}

\subsection{Study Area}

The study was conducted in Pulau Rambut Wildlife Sanctuary (106.5 $41^{\prime} 30^{\prime \prime}$ E, 5.5 58'30" S), a small island (45 ha) located in the Jakarta Bay area. There are three types of forest ecosystems in Pulau Rambut Wildlife Sanctuary. There is a coastal forest, lowland forest and mangrove forest. There are approximately 46 bird species which are divided into two major groups, namely waterbirds and terrestrial birds. The species of waterbirds found on Pulau Rambut is Egret species (Egretta spp.), Heron species (Ardea spp.), Black-crown night heron (Nycticorax nycticorax), Little black cormorant (Phalacrocorax sulcirostris), Little cormorant (Phalacrocorax niger). In addition to bird species, other species of fauna are also found, such as bats (Pteropus vampyrus), Asian water monitor (Varanus salvator), Mangrove snakes (Boiga dendrophila), and Pythons (Python sp.). 


\subsection{Field Method}

The tools used in this research are ArcGis 10.3 software, Global Positioning System (GPS), binoculars, camera, bird field guide book [5], and Microsoft excel. Data were collected at Pulau Rambut Wildlife Sanctuary in DKI Jakarta from 21 January - 17 February 2020.

The waterbirds group in this study consisted of the Ardeidae family. Birds were counted using the census method by determining one point of concentration for the census at the Pulau Rambut jetty. The location in the southern part of the island facing Java Island. This counted is used to obtain the abundance value of birds by calculating all individuals, whether in groups or not in groups. The count was carried out at $05.30-7.00 \mathrm{am}$ to count the birds from Pulau Rambut and 04.00-06.15 pm to measure the incoming birds to Pulau Rambut.

The count was made 14 times in the morning observations and 15 times in the evening. Little egrets, Intermediate egrets, and Cattle egrets are often observed in close location and are almost the same size and shape. Observation of the distribution pattern of nest trees was carried out by exploring Pulau Rambut. The coordinates of the nest tree were taken seven times on the island. The data taken were the types of nest trees, weather, wind conditions, and litter around the nest. We analyzed data on each waterbird species' maximum value based on bird counting in the morning and evening. The distribution of nest trees was analyzed spatially.

\section{RESULT AND DISCUSSION}

The Ardeidae family dominates waterbird species in Pulau Rambut, precisely eight species. The abundance of waterbirds in January-February 2020 is 3681 individuals (133 grey heron, 159 purple herons, 1391 egret species, 115 great egrets, 1129 black-crowned night heron). Weather, wind and tidal factors affect the daily number of birds [6].

The difference in morphology between the little egret and the intermediate egret is the beak's colour and the body's size. The little egret has a smaller body size and a black beak, while the intermediate egret beak is yellow (Figure 1). Cattle egret has an orange colour in the body (Figure 2). The species that is found in the least abundance is the Pacific reef heron. This species was observed in no more than two individuals in the morning and evening looking for food on the south coast of Pulau Rambut near the jetty.

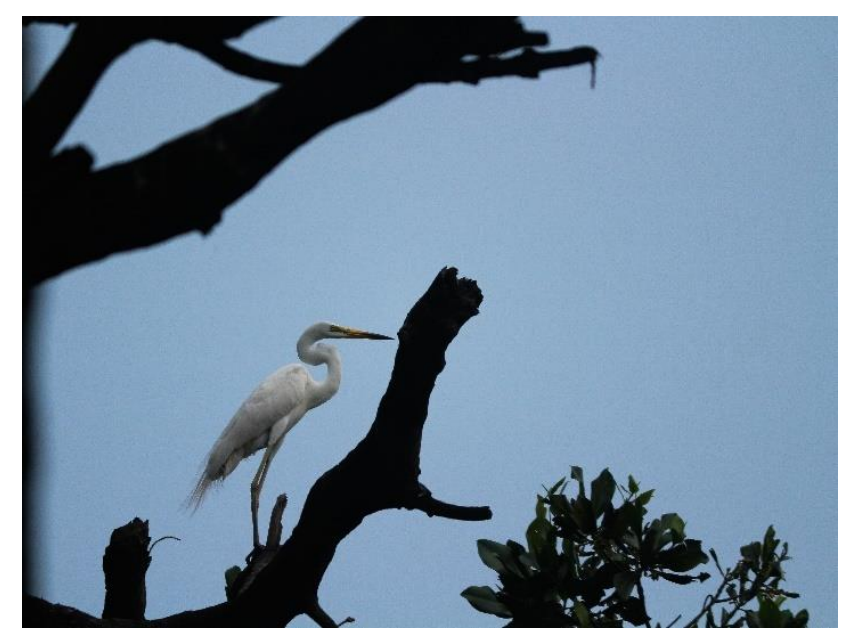

Figure 1 Intermediate egret (Egretta intermedia)

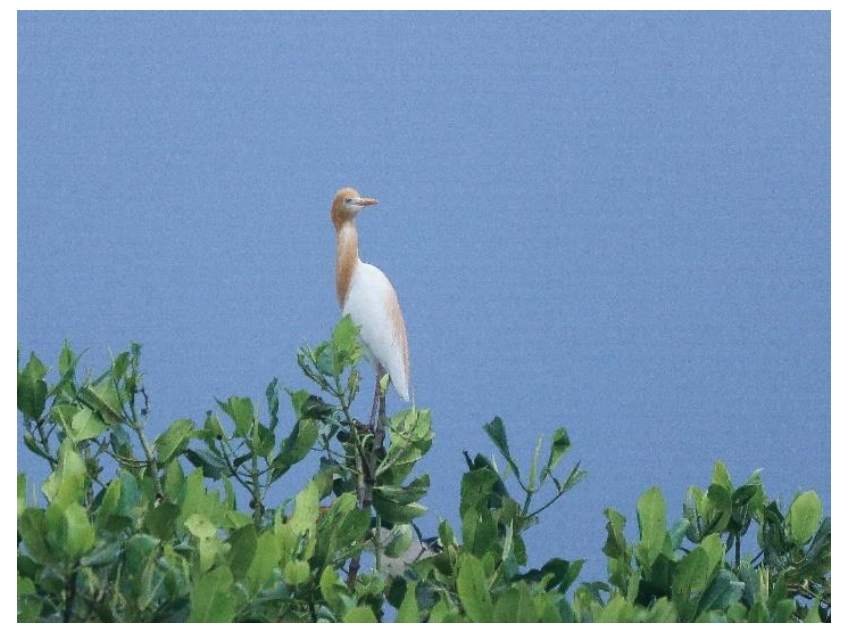

Figure 2 Cattle egret (Bubulcus ibis)

Based on the morning and evening averages, the waterbirds' count in January-February 2020 was less than the previous studies data in 1990 and 2001. The composition of the Ardeidae family in Pulau Rambut dominated by egret species $(47 \%)$ and black-crowned night heron (39\%) (Figure 3).

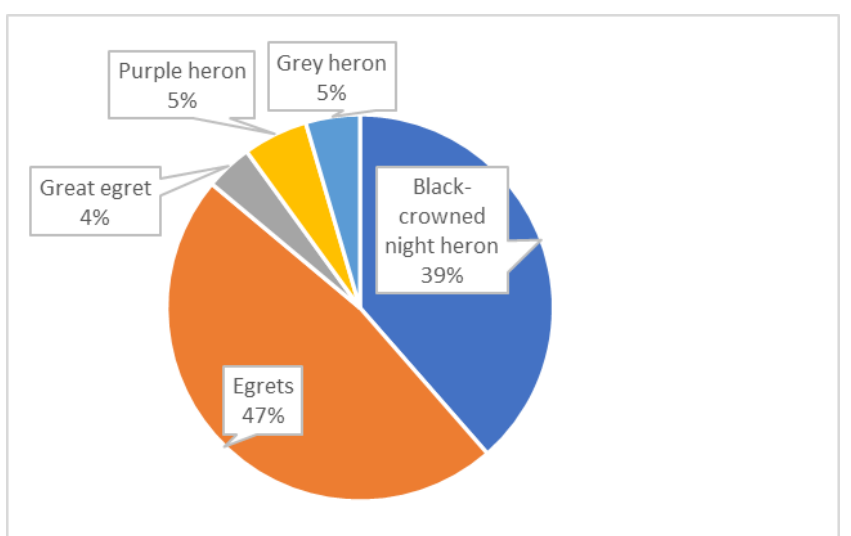

Figure 3. Composition of Ardeidae family 
There is a difference in the distribution of nest trees in January-February 2020 compared to nest trees' distribution data in January-March 1990 [8]. Most of the waterbirds nest on the eastern part of Pulau Rambut. There are 3sub-colony in the distribution of waterbirds on Pulau Rambut. In the part of the primary mangrove forest - the north gates, there are Purple heron and Great egret. The Black crowned-night heron can be found in primary mangrove forest parts in the middle - northeast floodgates. Grey heron, little egret, and intermediate egret inhabited eastern primary mangrove forest.

In January-February, the waterbirds in Pulau Rambut are scattered in the central and eastern parts of the primary mangrove forest in the north and northeast (Figure 4). The waterbirds occupy the Rhizophora mucronota community as a nest and perch located on the mangrove forest's edge. The vegetation criteria of $R$. mucronata as a nesting site are those with a height of 9$16 \mathrm{~m}$. The species that occupy the mixed forest are the milky stork, purple heron, grey heron, great egret and the cormorant species.

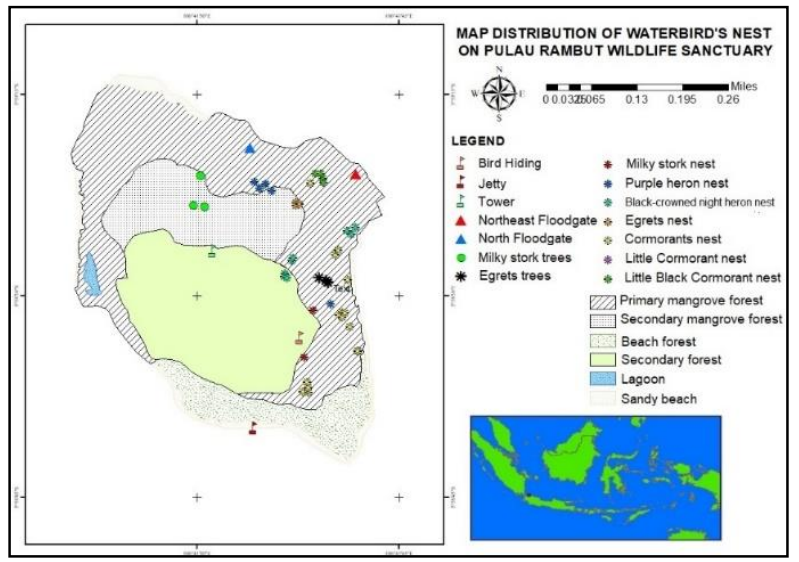

Figure 4 Map distribution of waterbirds in Pulau Rambut

Grey heron and purple are species from the Ardeidae family. In terms of size, the two species of birds are almost the same, but there are differences in body colour. The spread of the two species was not observed to be close to each other. Grey heron was observed to choose nest trees closer to the beach, which borders the milky stork's nest and is in the highest canopy of $R$. mucronata. While purple heron is in the middle mangrove forest near the north floodgate, there is some grey heron near purple heron. Still, not many were found (Figure 5).

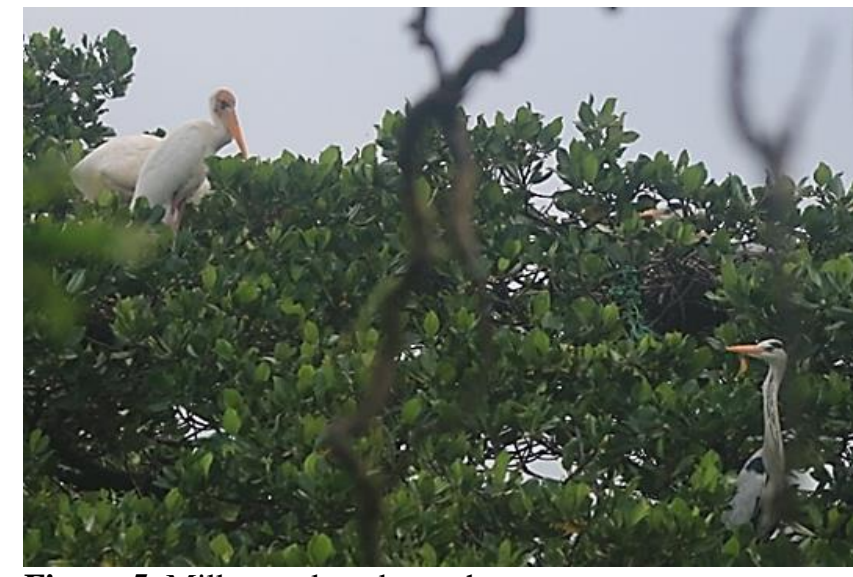

Figure 5. Milky stork and grey heron on same nest trees

Continuous accumulation of litter results in disruption of the cycle of sea water in and out during tides into mangroves. This affects forest vegetation's death and disturbed biota ecosystems in river flows, thus affecting nesting sites for waterbirds [11]. There tends to be less litter found in the eastern part of Pulau Rambut. There are many ropes to make a nest. The presence of a rope in the nest can cause the bird to become entangled in the rope.

Oil contamination exposure poses another threat to Pulau Rambut. As a result of the oil spill in 2019, oil exposure was found in the northern and north-eastern parts of primary mangrove forests on the mud substrate. They are categorized as areas with a heavy level of contamination [12]. The impact of exposure to oil pollution on mangrove forests cannot be seen in a short time [13]. This is anticipated by the management of the Pulau Rambut Wildlife Sanctuary, which routinely implements mangrove seedlings to rehabilitate the mangrove forests on Pulau Rambut. Mangrove forests are in good condition and growing but not evenly distributed throughout the area.

\section{CONCLUSION}

The abundance of the Ardeidae family in JanuaryFebruary 2020 is 3,681 individuals, lower than the 1990 and 2001 studies. There are three distribution areas for waterbirds nesting trees on Pulau Rambut. Monitoring measures regarding the abundance and distribution of nests of waterbirds in Pulau Rambut need to be taken to determine the availability of nests for waterbirds and clean up the trash regularly. Rehabilitation efforts in planting mangrove seedlings along the coast are expected to become new breeding areas for waterbirds.

\section{ACKNOWLEDGMENTS}

Sincere thanks are expressed to the Management of Pulau Rambut Wildlife Sanctuary for facilitating this study. The authors would also like to acknowledge reviewers for critical review of the manuscript. 


\section{REFERENCES}

[1]. F. Lambert, P. Erftemeijer, The waterbirds of Pulau Rambut, Java, Kukila, 4(3-4), 1989, pp. 109-118.

[2]. A. Mashudi, G. Marhento, Identifikasi keanekaragaman jenis burung dan kearifan tradisional masyarakat dalam upaya konservasi di Pulau Rambut Kepulauan Seribu, Jurnal Formatif, 6(2), 2016, pp. 119-124.

[3]. A. Azhar, Evaluasi terhadap kelimpahan dan pola penggunaan habitat bersarang burung merandai pada musim berbiak di Suaka Margasatwa Pulau Rambut [skripsi], Institut Pertanian Bogor, Bogor, 2002.

[4]. A. Mahmud, Kelimpahan dan pola penyebaran burung-burung merandai di Cagar Alam Pulau Rambut [skripsi]. Institut Pertanian Bogor, Bogor, 1991.

[5]. J. MacKinnon, K. Phillips, B. van Ballen, BurungBurung di Sumatera, Jawa, Bali, dan Kalimantan, Burung Indonesia, Bogor (ID), 2010.

[6]. M.R.R. Syahputra, I.K. Ginantra IK, A.A.G.D. Dalem, Aktivitas harian burung kuntul kecil (Egretta garzetta) di Pulau Serangan, Bali, Jurnal Biologi Udayana, 22(1), 2017, pp. 1-6.

[7]. R. Harel, O. Duriez, O. Spiegel, J. Fluhr, N. Horvitz, M.G. Wayne, W. Bouten, F. Sarrazin, Decision-making by a soaring bird: time, energy, and risk considerations at different spatio-temporal scale, Phill Trans R Sco B. 371: 20150397, 2016.

[8]. A. Mardiastuti, Habitat and nest-site characteristics of waterbirds in Pulau Rambut nature Sanctuary, Jakarta Bay, Indonesia [disertasi], Michigan State University, Michigan, 1992.

[9]. E. Jumilawaty, Morfometri dan kompetisi intraspesifik antara pecuk hitam (Phalacrocorax sulcirostris) dan pecuk kecil (Phalacrocorax niger) di koloni utara dan barat Suaka Margasatwa Pulau Rambut [tesis], Institut Pertanian Bogor, Bogor, 2002.

[10].G.A. Allport, S.A. Wilson, Result of a census of Milky stork (Mycteria cinerea) in West Java. Study Report No 14. International council for bird preservation, University of East Anglia Cambridge, 1986.

[11].Onrizal, Ancaman kelestarian Suaka Margasatwa Pulau Rambut dan alternatif rehabilitasinya, Bulletin Konservasi Alam, 4(1), 2004, pp. 21-24.

[12].A. Mardiastuti, Y.A. Mulyani, N.K.Y. Susanti, R.N. Ivonnie, C.A. Oktavia, Oil spill in Pulau Rambut and its possible long-term impact on mangrove as waterbirds habitat, IOP Conf. Ser.: Earth Environ. Sci. 528 012015, 2020.

[13].F. Reinert, C.D. Pinho, M.A. Ferreira, Diagnosing the level of stress on a mangrove species (Laguncularia racemosa) contaminated with oil: A necessary step for monitoring mangrove ecosystems, Marine Pollution Bulletin, 113, 2016, pp. 94-99. 